\title{
26. CHEMICAL AND MINERALOGICAL STUDIES, SITE 323
}

\author{
James I. Drever, Department of Geology, University of Wyoming, Laramie, Wyoming
}

\section{INTRODUCTION}

The purpose of this study was to provide data on the mineralogy and chemistry of the solid phases from Site 323 and to provide a basis for interpretation of the interstitial water chemistry and isotopic data reported elsewhere in this volume.

\section{EXPERIMENTAL METHODS}

The samples were dispersed in distilled water, washed to remove excess salts, and the clay fraction was separated by centrifugation. Initially the separation was made at $2 \mu \mathrm{m}$ esd (equivalent spherical diameter); however, at a meeting of geochemists working on Leg 35 materal, it was agreed that the separation should be made at $1 \mu \mathrm{m}$. Comparison of the $<2 \mu \mathrm{m}$ with the $<1$ $\mu \mathrm{m}$ fraction of the same sample (Table 1) suggests that the two are very similar in chemistry and mineralogy.

The clay fraction of each sample was examined by Xray diffraction using the sample preparation technique of Drever (1973), and analyzed chemically by atomic absorption spectrophotometry after dissolution in HF using the technique of Buckley and Cranston (1971). The $>2$ (or 1) $\mu \mathrm{m}$ fraction was examined by X-ray diffraction and scanning electron microscopy, and, for certain samples the zeolites were separated from other minerals by heavy liquid separation using dibromomethane.

\section{RESULTS AND DISCUSSION}

The chemical analyses are presented in Tables 1-5, and Figures 1 and 2. The routine X-ray diffraction results are not presented here, as they essentially duplicate the data presented in Zemmels and Cook (this volume).

Above 639 meters most components of the sediment are typical of land-derived material. The clays are a mixture of illite, smectite, chlorite, and kaolinite in varying proportions, and the dominant minerals in the silt fraction are quartz, feldspars (both K-feldspar and plagioclase), mica (at least some of which is biotite), chlorite, and biogenic silica. The silts above 639 meters also contain small amounts of clinoptilolite, which is presumably authigenic, and laumontite, whose origin is discussed below. The major and minor element chemistry of the clay fraction above 639 meters is quite uniform (Figures 1 and 2), which is consistent with the idea that the material is relatively unmodified terrigenous debris. The $\mathrm{CaO}$ content of the coarse fraction above 639 meters does decrease with depth (Table 3 ), which would be consistent with progressive alteration of plagioclase (see Kastner, this volume).

At approximately 639 meters (in Core 14 , Section 2) there is an abrupt change in mineralogy and chemistry. The dominant mineral in the clay fraction below this depth is a smectite showing no evidence of mixed layering, with minor illite, clinoptilolite, and quartz. The major element chemistry of the clay fraction shows large variations which do not appear to correlate with variations in mineralogy observed by X-ray diffraction. The transition metals and strontium are highly enriched between 639 and 670 meters (Table 2 and Figure 2). Presumably this represents the ferromanganese material described originally by Boström and Peterson (1966) from the East Pacific Rise, and subsequently encountered immediately above basement in many DSDP cores. There are two notable aspects of the transition metal distribution at Site 323. First, the enriched zone is 30-74 meters above the basement, and the basal 30 meters of sediment is generally not enriched in transition metals. If the ferromanganese-rich sediments are much younger than the lowermost basal sediments, as suggested by the shipboard paleontologic studies, it may be difficult to relate the source of the metals directly to spreading-center activity. Second, although all the transition metals analyzed are enriched in the same 31meters interval, the correlations between individual pairs of elements within this interval are not at all close. This suggests either that the source of the metals was variable, or that some postdepositional migration has taken place.

Barium in the clay fraction shows a distribution unlike that of any other element analyzed. It is relatively uniform throughout the core with the exception of a sharp maximum immediately above the basement.

From 639 to 669 meters the principal minerals of the silt fraction are quartz, feldspar (both $\mathrm{K}$-feldspar and plagioclase), mica, and smectite, with calcite occurring between 663 and 669 meters. Below 669 meters the assemblage is quartz, K-feldspar, smectite, clinoptilolite, and plagioclase. Laumontite was found in one sample only, $18-4,10-11 \mathrm{~cm}$. Under the scanning electron microscope the $\mathrm{K}$-feldspar appears as large (10-30 $\mu \mathrm{m})$ angular grains whose morphology suggests that they are authigenic. The clinoptilolite appears as irregularly shaped laths which are typically $5 \mu \mathrm{m}$ or less in length. The chemical analysis of an essentially pure clinoptilolite fraction from heavy liquid separations is given in Table 5.

The change in mineralogy and chemistry at 639 meters suggests a change from a dominantly volcanic source for the basal sediments to a dominantly terrigenous source for the sediments in the upper part of the core.

The $<0.2 \mu \mathrm{m}$ fraction was separated from selected samples by centrifugation and analyzed chemically (Table 4) and mineralogically. It is in this fraction that mixed-layer illite-smectites are most easily studied, and diagenetic changes in illite-smectites are most apparent. 
TABLE 1

Major Element Composition of Clay Fraction, Site 323

\begin{tabular}{|c|c|c|c|c|c|c|c|c|c|}
\hline $\begin{array}{c}\text { Sample }{ }^{\mathrm{a}} \\
\text { (Interval in } \mathrm{cm} \text { ) }\end{array}$ & $\begin{array}{l}\text { Depth } \\
\text { (m) }\end{array}$ & $\mathrm{SiO}_{2}$ & $\mathrm{Al}_{2} \mathrm{O}_{3}$ & $\mathrm{Fe}_{2} \mathrm{O}_{3}{ }^{\mathrm{b}}$ & $\mathrm{CaO}$ & $\mathrm{MgO}$ & $\mathrm{Na}_{2} \mathrm{O}$ & $\mathrm{K}_{2} \mathrm{O}$ & $\mathrm{MnO}^{\mathrm{c}}$ \\
\hline $1-5,0-15(2)$ & 81.5 & 57.3 & 13.7 & 9.3 & 0.77 & 3.34 & 1.21 & 3.00 & 0.10 \\
\hline $1-5,0-15(1)$ & 81.5 & 55.5 & 13.7 & 9.5 & 0.77 & 3.46 & 1.20 & 3.13 & 0.10 \\
\hline $2-2,0-15(1)$ & 162.5 & 55.2 & 15.8 & 8.9 & 1.13 & 3.56 & 1.44 & 3.17 & 0.07 \\
\hline $3, \mathrm{CC}(1)$ & 265.5 & 59.0 & 15.0 & 10.8 & 1.26 & 4.08 & 0.95 & 2.03 & 0.13 \\
\hline $4, \mathrm{CC}(1)$ & 322.5 & 54.6 & 15.7 & 7.6 & 1.07 & 3.38 & 1.12 & 3.19 & 0.08 \\
\hline $7-3,31-46(1)$ & 367.5 & 59.0 & 14.6 & 9.7 & 1.10 & 3.59 & 1.67 & 3.28 & 0.10 \\
\hline $8, \mathrm{CC}(1)$ & 417.5 & 54.6 & 14.9 & 9.6 & 0.97 & 3.73 & 1.40 & 3.16 & 0.08 \\
\hline $9-2,0-10(1)$ & 457 & 55.2 & 15.3 & 9.4 & 1.06 & 3.86 & 1.29 & 3.04 & 0.11 \\
\hline 9, CC (1) & 465 & 59.3 & 14.9 & 7.0 & 0.91 & 2.94 & 1.03 & 3.35 & 0.19 \\
\hline $10-3,0-12(1)$ & 506 & 57.2 & 14.4 & 9.1 & 0.99 & 3.29 & 1.34 & 3.30 & 0.14 \\
\hline $11-1,0-10(1)$ & 550.5 & 60.5 & 17.4 & 7.3 & 0.93 & 3.06 & 1.02 & 3.64 & 0.13 \\
\hline $11-1,86-87(2)$ & 551.5 & 55.8 & 17.0 & 7.1 & 0.95 & 2.93 & 1.23 & 3.60 & 0.14 \\
\hline $11-2,75-76(2)$ & 553 & 56.1 & 15.9 & 7.4 & 0.94 & 3.02 & 1.07 & 3.40 & 0.15 \\
\hline $12-1,135-150(1)$ & 599.5 & 54.8 & 18.4 & 7.3 & 0.75 & 3.25 & 1.07 & 4.66 & 0.08 \\
\hline $13-5,125-126(2)$ & 624 & 49.5 & 18.2 & 10.1 & 0.92 & 3.25 & 1.42 & 3.70 & 0.26 \\
\hline $13-5,135-150(1)$ & 624.5 & 56.9 & 20.0 & 8.6 & 0.94 & 3.80 & 0.92 & 4.00 & 0.15 \\
\hline $13, \mathrm{CC}(2)$ & 626.5 & 52.4 & 18.7 & 8.6 & 0.99 & 3.15 & 1.40 & 4.30 & 0.26 \\
\hline $14-1,140-150(1)$ & 637.5 & 56.2 & 18.4 & 12.0 & 1.00 & 3.47 & 1.00 & 3.75 & 0.26 \\
\hline $14-2,10-11(2)$ & 637.5 & 50.0 & 17.7 & 10.1 & 0.88 & 2.94 & 1.62 & 3.40 & 0.22 \\
\hline $14-2,10-11(1)$ & 637.5 & 50.0 & 18.0 & 10.0 & 0.83 & 3.03 & n.d. ${ }^{d}$ & 3.31 & 0.22 \\
\hline $14-2,61-62(2)$ & 638 & 52.7 & 18.4 & 8.4 & 0.82 & 3.11 & 1.40 & 3.80 & 0.11 \\
\hline $14-2,99-100(2)$ & 638.5 & 43.3 & 15.6 & 13.6 & 1.46 & 2.69 & 1.62 & 1.35 & 3.25 \\
\hline 14, CC (2) & 645.5 & 43.1 & 15.5 & 14.4 & 1.39 & 2.71 & 1.71 & 1.33 & 3.28 \\
\hline $14, \mathrm{CC}(1)$ & 645.5 & 43.5 & 15.9 & 14.9 & 1.45 & 2.84 & 1.83 & 1.50 & 2.75 \\
\hline $15-1,39-40(2)$ & 655.5 & 38.0 & 13.9 & 19.1 & 1.27 & 2.67 & 1.49 & 1.25 & 4.61 \\
\hline $15-3,76-77(2)$ & 659 & 46.8 & 17.0 & 13.5 & 1.20 & 2.85 & 1.52 & 1.60 & 2.38 \\
\hline $15-5,140-150(1)$ & 662.5 & 50.0 & 19.0 & 15.1 & 2.00 & 2.93 & 0.41 & 2.46 & 2.71 \\
\hline $15-6,47-48(2)$ & 663 & 29.2 & 12.2 & 9.4 & 16.8 & 1.81 & 1.82 & 1.23 & 2.75 \\
\hline $16-1,52-53(2)$ & 665 & 34.4 & 11.1 & 8.3 & 13.0 & 2.47 & 1.94 & 1.11 & 4.13 \\
\hline $16-2,19-21(2)$ & 666 & 30.7 & 9.9 & 7.5 & 18.7 & 2.42 & 2.37 & 0.89 & 1.06 \\
\hline $16-2,56-58(2)$ & 666.5 & 42.1 & 11.8 & 8.0 & 10.2 & 3.41 & 2.57 & 0.80 & 0.44 \\
\hline $16-2,142-143(2)$ & 667.5 & 54.5 & 14.3 & 9.9 & 1.43 & 3.89 & 2.00 & 1.12 & 0.84 \\
\hline $16-3,27-29(2)$ & 668 & 54.6 & 14.0 & 10.2 & 1.32 & 3.76 & 2.00 & 0.79 & 0.97 \\
\hline $16-3,27-29(1)$ & 668 & 53.3 & 14.8 & 10.1 & 1.34 & n.d. & 2.20 & 0.74 & 1.05 \\
\hline $16-3,130-132(2)$ & 669 & 52.9 & 13.0 & 12.5 & 1.28 & 3.08 & 1.89 & 0.70 & 2.06 \\
\hline $16-4,72-73(2)$ & 670 & 53.5 & 12.9 & 14.5 & 1.45 & 3.09 & 2.23 & 0.93 & 0.70 \\
\hline $17-6,133-135(2)$ & 683.5 & 52.4 & 13.7 & 11.3 & 1.57 & 3.00 & 2.00 & 1.10 & 0.60 \\
\hline $18-2,132-133(2)$ & 696 & 52.0 & 15.0 & 11.3 & 1.07 & 2.80 & 2.00 & 1.48 & 0.11 \\
\hline $18-4,10-11(2)$ & 697.5 & 55.5 & 14.0 & 12.0 & 1.08 & 2.84 & 1.79 & 1.46 & 0.13 \\
\hline $18-5,147-150(2)$ & 700.5 & 48.2 & 10.8 & 15.2 & 1.17 & 3.04 & 3.11 & 1.35 & 0.31 \\
\hline $18-6,4-6(2)$ & 701 & 53.6 & 11.0 & 15.2 & 1.20 & 3.54 & 1.86 & 1.28 & 0.20 \\
\hline $18-6,4-6(1)$ & 701 & 53.5 & 11.6 & 15.2 & 1.23 & 3.69 & 2.05 & 1.34 & 0.20 \\
\hline
\end{tabular}

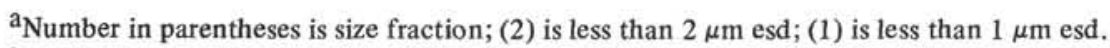

${ }^{\text {b }}$ Total iron reported as $\mathrm{Fe}_{2} \mathrm{O}_{3}$.

Total manganese reported as $\mathrm{MnO}$.

$\mathrm{d}_{\text {n.d. }}=$ Not determined .

In Cores 15 and 16 the only mineral identifiable by Xray diffraction is a smectite which is essentially $100 \%$ expandable (by the criteria of Reynolds and Hower, 1970). The low $\mathrm{K}_{2} \mathrm{O}$ contents are consistent with the mineralogic interpretation. Samples $13-5,125-126 \mathrm{~cm}$ and $14-2,10-11 \mathrm{~cm}$ contain a mixed-layer illite-smectite with approximately $60 \%-70 \%$ expandable layers, and traces of discrete illite. These samples have much higher $\mathrm{K}_{2} \mathrm{O}$ contents, which is again consistent with the mineralogy. Sample 14-2, 99-100 cm contains a more expanded illite-smectite (approximately $80 \%$ ) plus traces of discrete illite. The mixed-layer clays in the upper two samples are typical of terrigenous weathering products, while the clays in the lower samples are typical of altered ash. The clays in the lower samples show no evidence of the type of diagenesis described by Perry and Hower
(1970) for sediments from the Gulf Coast, suggesting that these clays had not been subjected to temperatures greater than $90^{\circ} \mathrm{C}$.

\section{Laumontite}

Laumontite, a calcic zeolite with the approximate formula $\mathrm{CaAl}_{2} \mathrm{Si}_{4} \mathrm{O}_{12} \cdot 4 \mathrm{H}_{2} \mathrm{O}$, was positively identified in Samples 2-2, 0-15 cm; 4, CC; 7-3, 31-46 cm; and in one subsample from $18-4,10-11 \mathrm{~cm}$. Laumontite was tentatively identified in some other samples from the core above 640 meters, and we believe that the material referred to as $U-1$ in the X-ray diffraction data (Zemmels and Cook, this volume) is probably laumontite.

The X-ray identification is based on the presence of peaks at $9.6 \AA$ and $6.86 \AA$ in the untreated heavy liquid 
TABLE 2

Minor Element Concentrations in Clay Fraction, Site 323

\begin{tabular}{|c|c|c|c|c|c|c|c|c|c|c|}
\hline $\begin{array}{c}\text { Sample }^{\mathrm{a}} \\
\text { (Interval in } \mathrm{cm} \text { ) }\end{array}$ & $\begin{array}{l}\text { Depth } \\
\text { (m) }\end{array}$ & $\begin{array}{c}\mathrm{Mn} \\
(\mathrm{wt} \%)\end{array}$ & $\begin{array}{c}\mathrm{Cu} \\
\text { (ppm) }\end{array}$ & $\begin{array}{l}\mathrm{Zn} \\
\text { (ppm) }\end{array}$ & $\begin{array}{c}\text { Co } \\
\text { (ppm) }\end{array}$ & $\begin{array}{c}\mathrm{Ni} \\
\text { (ppm) }\end{array}$ & $\begin{array}{c}\mathrm{Pb} \\
\text { (ppm) }\end{array}$ & $\begin{array}{c}\text { Mo } \\
\text { (ppm) }\end{array}$ & $\begin{array}{c}\mathrm{Sr} \\
(\mathrm{ppm})\end{array}$ & $\begin{array}{c}\mathrm{Ba} \\
(\mathrm{ppm})\end{array}$ \\
\hline $1-5,0-15(1)$ & 81.5 & 0.08 & 115 & 200 & 60 & 90 & 85 & $<4$ & 140 & 1200 \\
\hline $1-5,0-15$ (2) & 81.5 & 0.08 & 145 & 180 & 60 & 90 & n.d. ${ }^{b}$ & n.d. & 120 & 1000 \\
\hline $2-2,0-15(1)$ & 162.5 & 0.05 & 225 & 165 & 25 & 35 & n.d. & n.d. & 160 & 640 \\
\hline 3, CC (1) & 265.5 & 0.10 & 140 & 180 & 28 & 50 & n.d. & n.d. & 200 & 240 \\
\hline 4, CC (1) & 322.5 & 0.06 & 55 & 165 & 22 & 30 & n.d. & n.d. & 160 & 400 \\
\hline $7-3,31-46(1)$ & 367.5 & 0.08 & 130 & 180 & 40 & 60 & n.d. & n.d. & 160 & 800 \\
\hline $8, C C(1)$ & 417.5 & 0.06 & 145 & 140 & 27 & 55 & n.d. & n.d. & 200 & 640 \\
\hline $9-2,0-10(1)$ & 457 & 0.09 & 230 & 210 & 32 & 50 & n.d. & n.d. & 120 & 680 \\
\hline 9, CC (1) & 465 & 0.15 & 40 & 110 & 17 & 20 & n.d. & n.d. & 160 & 440 \\
\hline $10-3,0-12(1)$ & 506 & 0.11 & 135 & 185 & 37 & 50 & n.d. & n.d. & 200 & 600 \\
\hline $11-1,0-10(1)$ & 550.5 & 0.10 & 43 & 120 & 22 & 30 & n.d. & n.d. & 160 & 440 \\
\hline $11-1,86-87(2)$ & 551.5 & 0.11 & 50 & 200 & 30 & 55 & 60 & $<4$ & 160 & 500 \\
\hline $11-2,75-76(2)$ & 553 & 0.12 & 60 & 425 & 40 & 55 & 80 & $<4$ & 140 & 300 \\
\hline $12-1,135-150(1)$ & 599.5 & 0.06 & 35 & 90 & 20 & 30 & n.d. & n.d. & 160 & 560 \\
\hline $13-5,125-126(2)$ & 624 & 0.20 & 120 & 210 & 50 & 100 & 85 & $<4$ & 160 & 400 \\
\hline $13-5,135-150$ (1) & 624.5 & 0.12 & 150 & 180 & 50 & 75 & n.d. & n.d. & 160 & 640 \\
\hline $13, \mathrm{CC}(2)$ & 626.5 & 0.20 & 120 & 208 & 60 & 100 & 60 & 9 & 170 & 800 \\
\hline $14-1,140-150(1)$ & 637.5 & 0.20 & 165 & 210 & 47 & 115 & n.d. & n.d. & 80 & 400 \\
\hline $14-2,10-11(2)$ & 637.5 & 0.17 & 148 & 180 & 50 & 110 & 75 & 5 & 140 & 600 \\
\hline $14-2,61-62$ & 638 & 0.09 & 106 & 160 & 115 & 130 & 60 & 5 & 190 & 500 \\
\hline $14-2,99-100(2)$ & 638.5 & 2.52 & 500 & 220 & 145 & 370 & 110 & 47 & 330 & 1200 \\
\hline 14, CC (2) & 645.5 & 2.54 & 600 & 270 & 170 & 440 & 150 & 50 & 380 & 900 \\
\hline $15-1,39-40(2)$ & 655.5 & 3.57 & 500 & 500 & 110 & 670 & 100 & 180 & 760 & 1000 \\
\hline $15-3,76-77(2)$ & 659 & 1.84 & 310 & 300 & 100 & 240 & 110 & 95 & 490 & 300 \\
\hline $15-5,140-150(1)$ & 662.5 & 2.10 & 225 & 195 & 65 & 150 & n.d. & n.d. & 320 & 600 \\
\hline $15-6,47-48(2)$ & 663 & 2.13 & 210 & 270 & 70 & 150 & 110 & 70 & 560 & 500 \\
\hline $16-1,52-53(2)$ & 665 & 3.20 & 170 & 220 & 90 & 100 & 90 & 30 & 540 & 800 \\
\hline $16-2,19-21(2)$ & 666 & 0.82 & 170 & 235 & 35 & 80 & 100 & $<4$ & 630 & 100 \\
\hline $16-2,56-58(2)$ & 666.5 & 0.34 & 175 & 230 & 30 & 100 & 50 & $<4$ & 430 & 100 \\
\hline $16-2,142-143(2)$ & 667.5 & 0.65 & 170 & 250 & 40 & 85 & 45 & $<4$ & 130 & 100 \\
\hline $16-3,27-29(2)$ & 668 & 0.75 & 175 & 235 & 75 & 100 & 40 & $<4$ & 130 & 100 \\
\hline $16-3,130-132(2)$ & 669 & 1.60 & 210 & 265 & 50 & 100 & 50 & 10 & 170 & 900 \\
\hline $16-4,72-73(2)$ & 670 & 0.54 & 200 & 310 & 50 & 135 & 55 & $<4$ & 130 & 100 \\
\hline $17-6,133-135(2)$ & 683.5 & 0.46 & 310 & 280 & 60 & 120 & 95 & $<4$ & 150 & 100 \\
\hline $18-2,132-133(2)$ & 696 & 0.09 & 200 & 250 & 40 & 100 & 65 & 4 & 170 & 800 \\
\hline $18-4,10-11(2)$ & 697.5 & 0.10 & 370 & 280 & 40 & 105 & 80 & $<4$ & 250 & 2500 \\
\hline $18-5,147-150(2)$ & 700.5 & 0.24 & 380 & 265 & 40 & 220 & 90 & $<4$ & 170 & 3500 \\
\hline $18-6,4-6(2)$ & 701 & 0.15 & 250 & 260 & 35 & 200 & 60 & $<4$ & 230 & 4000 \\
\hline
\end{tabular}

${ }^{a}$ Number in parentheses is size fraction; (2) is less than $2 \mu \mathrm{m}$ esd; (1) is less than $1 \mu \mathrm{m}$ esd.

$\mathrm{b}_{\mathrm{n} . \mathrm{d} .}=$ Not determined.

separate. On heating to $350^{\circ} \mathrm{C}$ for $4 \mathrm{hr}$ these peaks disappear and are replaced by peaks at $10.8 \AA, 8.6-8.8 \AA$, and $6.3 \AA$ (Furbish, 1965). In the subsample of $18-4,10$ $11 \mathrm{~cm}$ which contained laumontite (a later subsample contained no detectable laumontite), the laumontite occurs as euhedral laths approximately $100 \mu \mathrm{m}$ in length. Energy-dispersive X-ray analysis of the grains of the scanning electron microscope shows no detectable $\mathrm{Na}$ or $\mathrm{K}$ and a Si/Al ratio (atomic) of approximately 2.5:1. Clinoptilolite from the same sample has easily detectable $\mathrm{Na}, \mathrm{K}$, and $\mathrm{Ca}$, and an $\mathrm{Si} / \mathrm{Al}$ ratio of approximately $4.5: 1$. The laumontite in Cores 2,4 , and 7 , by contrast, appears to have a grain size of $5 \mu \mathrm{m}$ or less.

The origin and significance of the laumontite is still under investigation. The common occurrences of laumontite are in zeolite facies metamorphic rocks. Laumontite-rich rocks of Lower Cretaceous age are exposed on adjacent areas of Antarctica (Horn, 1968), so that it is conceivable that the laumontite is detrital. If this is the case the sediments should contain abundant epidote which occurs with the laumontite in Antarctica (J.R. Boles, personal communication). If the laumontite is found to be authigenic, related perhaps to the high calcium concentrations in the interstitial water, this will have great significance in zeolite facies metamorphism. At present there is debate as to the relative importance of pressure and temperature compared to chemical factors in determining zeolite mineralogy (Boles and Coombs, 1975). The formation of laumontite at low temperatures and pressures would be a critical datum for this problem.

\section{Clay Vein in Basalt}

We analyzed one small fragment of a clay vein (18-6, $73-83 \mathrm{~cm}$ ). Mineralogically it consists of a smectite plus calcite plus quartz. Chemically (Table 5) it has an $\mathrm{Mg} / \mathrm{Al}$ ratio (atomic) of $1.9: 1$ and an $\mathrm{Mg} / \mathrm{Fe}$ ratio of $1.8: 1$, indicating that the smectite should be classified as a saponite.

\section{Altered Basalt}

We received one small chip of basalt (18-6, 14-15 cm, part of which was reddish-brown in color, and part gray. Chemical analyses (Table 5) suggest that the color 
TABLE 3

Major Element Composition of Coarse Fraction, Site 323

\begin{tabular}{llllllllll}
\hline $\begin{array}{c}\text { Sample } \\
\text { (Interval in cm) }\end{array}$ & $\begin{array}{c}\text { Depth } \\
(\mathrm{m})\end{array}$ & $\mathrm{SiO}_{2}$ & $\mathrm{Al}_{2} \mathrm{O}_{3}$ & $\mathrm{Fe}_{2} \mathrm{O}_{3}{ }^{\mathrm{b}}$ & $\mathrm{CaO}$ & $\mathrm{MgO}$ & $\mathrm{Na}_{2} \mathrm{O}$ & $\mathrm{K}_{2} \mathrm{O}$ & $\mathrm{MnO}^{\mathrm{c}}$ \\
\hline $1-5,0-15(1)$ & 81.5 & 67.0 & 11.3 & 3.74 & 1.42 & 1.69 & 2.36 & 2.75 & 0.06 \\
$3, \mathrm{CC}(1)$ & 265.5 & 63.3 & 12.4 & 3.14 & 3.18 & 1.48 & 2.94 & 2.42 & 0.70 \\
$8, \mathrm{CC}(1)$ & 417.5 & 65.1 & 12.4 & 3.02 & 2.47 & 1.32 & 3.06 & 2.45 & 0.21 \\
$9-2,0-10(1)$ & 457 & 63.3 & 13.4 & 4.38 & 3.76 & 1.57 & 3.26 & 2.02 & 0.50 \\
$9, \mathrm{CC}(1)$ & 465 & 69.7 & 11.9 & 3.72 & 1.49 & 1.30 & 2.61 & 3.00 & 0.06 \\
$11-1,0-10(1)$ & 550.5 & 67.7 & 12.1 & 3.69 & 1.26 & 1.34 & 2.64 & 3.31 & 0.10 \\
$12-1,135-150(1)$ & 599.5 & 69.9 & 12.7 & 3.47 & 1.37 & 1.51 & 2.29 & 3.33 & 0.05 \\
$13-5,125-126(2)$ & 624 & 66.6 & 12.4 & 4.89 & 1.30 & 1.82 & 2.12 & 3.28 & 0.19 \\
$13, \mathrm{CC}(2)$ & 626.5 & 71.3 & 10.2 & 2.89 & 1.11 & 1.14 & 2.07 & 3.00 & 0.36 \\
$14-2,10-11(2)$ & 637.5 & 74.5 & 10.1 & 2.75 & 0.84 & 1.15 & 2.02 & 3.06 & 0.09 \\
$14-2,61-62(2)$ & 638 & 70.2 & 11.7 & 3.50 & 0.62 & 1.54 & 1.72 & 3.84 & 0.06 \\
$14-2,99-100(2)$ & 638.5 & 57.4 & 13.8 & 7.30 & 2.35 & 2.13 & 2.23 & 3.33 & 1.18 \\
$14, \mathrm{CC}(2)$ & 645.5 & 58.5 & 14.2 & 7.60 & 2.04 & 2.20 & 2.35 & 3.42 & 1.10 \\
$15-3,76-77(2)$ & 659 & 58.5 & 15.5 & 7.80 & 1.49 & 2.10 & 2.03 & 4.35 & 0.83 \\
$15-6,47-48(2)$ & 663 & 22.0 & 6.80 & 4.48 & 32.0 & 0.90 & 0.36 & 1.65 & 1.07 \\
$16-1,52-53(2)$ & 665 & 29.7 & 7.50 & 4.00 & 29.0 & 1.24 & 0.52 & 2.07 & 1.09 \\
$16-2,19-21(2)$ & 666 & 36.4 & 9.00 & 5.23 & 20.0 & 1.75 & 0.67 & 2.35 & 0.58 \\
$16-2,56-58(2)$ & 666.5 & 40.3 & 9.90 & 4.71 & 18.2 & 1.93 & 0.80 & 2.55 & 0.36 \\
$16-2,142-143(2)$ & 667.5 & 59.3 & 14.1 & 5.12 & 1.42 & 2.02 & 1.62 & 5.28 & 0.27 \\
$16-3,27-29(2)$ & 668 & 59.8 & 13.7 & 6.90 & 2.14 & 2.39 & 1.83 & 4.09 & 0.34 \\
$16-3,130-132(2)$ & 669 & 55.2 & 12.8 & 8.60 & 1.42 & 2.43 & 2.05 & 2.96 & 1.00 \\
$16-4,72-73(2)$ & 670 & 58.3 & 12.9 & 7.80 & 1.60 & 1.95 & 2.42 & 3.32 & 0.34 \\
$18-2,132-133(2)$ & 696 & 60.9 & 13.8 & 4.89 & 1.14 & 1.52 & 2.49 & 4.30 & 0.00 \\
$18-6,4-6(2)$ & 701 & 57.4 & 10.5 & 8.80 & 1.52 & 2.14 & 1.39 & 3.86 & 0.16 \\
\hline
\end{tabular}

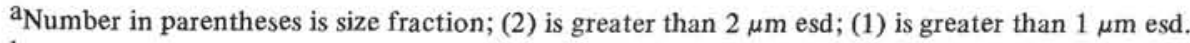

${ }^{\mathrm{b}}$ Total iron reported as $\mathrm{Fe}_{2} \mathrm{O}_{3}$.

${ }^{\mathrm{c}}$ Total manganese reported as $\mathrm{MnO}$.

TABLE 4

Major Element Composition of the $<\mathbf{0 . 2} \mu \mathrm{m}$ Fraction, Site 323

\begin{tabular}{llllllllll}
\hline $\begin{array}{c}\text { Sample } \\
\text { (Interval in cm) }\end{array}$ & $\begin{array}{c}\text { Depth } \\
(\mathrm{m})\end{array}$ & $\mathrm{SiO}_{2}$ & $\mathrm{Al}_{2} \mathrm{O}_{3}$ & $\mathrm{Fe}_{2} \mathrm{O}_{3}{ }^{\mathrm{a}}$ & $\mathrm{CaO}$ & $\mathrm{MgO}$ & $\mathrm{Na}_{2} \mathrm{O}$ & $\mathrm{K}_{2} \mathrm{O}$ & $\mathrm{MnO}^{\mathrm{b}}$ \\
\hline $13-5,125-126$ & 624 & 48.6 & 15.4 & 11.2 & 1.00 & 3.42 & 1.88 & 2.60 & 0.31 \\
$14-2,10-11$ & 637.5 & 48.8 & 15.3 & 11.1 & 1.09 & 3.11 & 1.79 & 2.40 & 0.25 \\
$14-2,99-100$ & 638.5 & 43.1 & 13.6 & 14.0 & 1.57 & 2.76 & 2.22 & 1.00 & 3.66 \\
$15-1,39-40$ & 655.5 & 40.3 & 12.0 & 18.0 & 1.31 & 2.74 & 2.03 & 0.80 & 4.91 \\
$15-5,140-150$ & 662.5 & 41.5 & 15.1 & 13.3 & 1.90 & 2.59 & 1.78 & 1.23 & 3.55 \\
$16-2,19-21$ & 666 & 48.2 & 11.6 & 10.4 & 2.84 & 3.57 & 2.77 & 0.71 & 1.62 \\
$16-2,56-58$ & 666.5 & 46.0 & 10.8 & 8.20 & 4.00 & 3.87 & 4.40 & 0.61 & 0.51 \\
$16-2,142-143$ & 667.5 & 49.5 & 12.2 & 9.40 & 1.44 & 3.89 & 2.94 & 0.80 & 0.98 \\
$16-4,72-73$ & 670 & 49.6 & 10.4 & 14.3 & 1.36 & 3.05 & 3.02 & 0.56 & 0.78 \\
\hline \\
a Total iron reported as $\mathrm{Fe}_{2} \mathrm{O}_{3}$.
\end{tabular}

TABLE 5

Chemical Analyses of Basalt and Clinoptilolite Separate, Site 323

\begin{tabular}{|c|c|c|c|c|c|c|c|c|}
\hline $\mathrm{SiO}_{2}$ & $\mathrm{Al}_{2} \mathrm{O}_{3}$ & $\mathrm{Fe}_{2} \mathrm{O}_{3}{ }^{\mathrm{a}}$ & $\mathrm{CaO}$ & $\mathrm{MgO}$ & $\mathrm{Na}_{2} \mathrm{O}$ & $\mathrm{K}_{2} \mathrm{O}$ & $\mathrm{MnO}^{\mathrm{b}}$ & $\mathrm{TiO}_{2}$ \\
\hline \multicolumn{9}{|c|}{ Reddish-stained portion of basalt chip, $18-6,14-15 \mathrm{~cm}$} \\
\hline 50.5 & 18.7 & 6.0 & 7.5 & 1.09 & 3.27 & 2.72 & 0.34 & 2.25 \\
\hline \multicolumn{9}{|c|}{ Gray colored portion of same chip } \\
\hline 52.5 & 19.2 & 6.3 & 7.1 & 1.23 & 3.20 & 3.04 & 0.13 & 2.31 \\
\hline \multicolumn{9}{|c|}{ Smectite plus calcite vein in basalt, $18-6,72-73 \mathrm{~cm}$} \\
\hline 40.4 & 5.2 & 7.2 & 10.7 & 10.7 & 0.3 & 1.17 & 2.63 & 0.2 \\
\hline \multicolumn{9}{|c|}{ Clinoptilolite separated from $18-4,10-11 \mathrm{~cm}$} \\
\hline 67.0 & 12.8 & 1.5 & 1.16 & 0.67 & 3.67 & 1.88 & 0.02 & $<0.1$ \\
\hline
\end{tabular}

aTotal iron reported as $\mathrm{Fe}_{2} \mathrm{O}_{3}$.

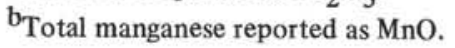




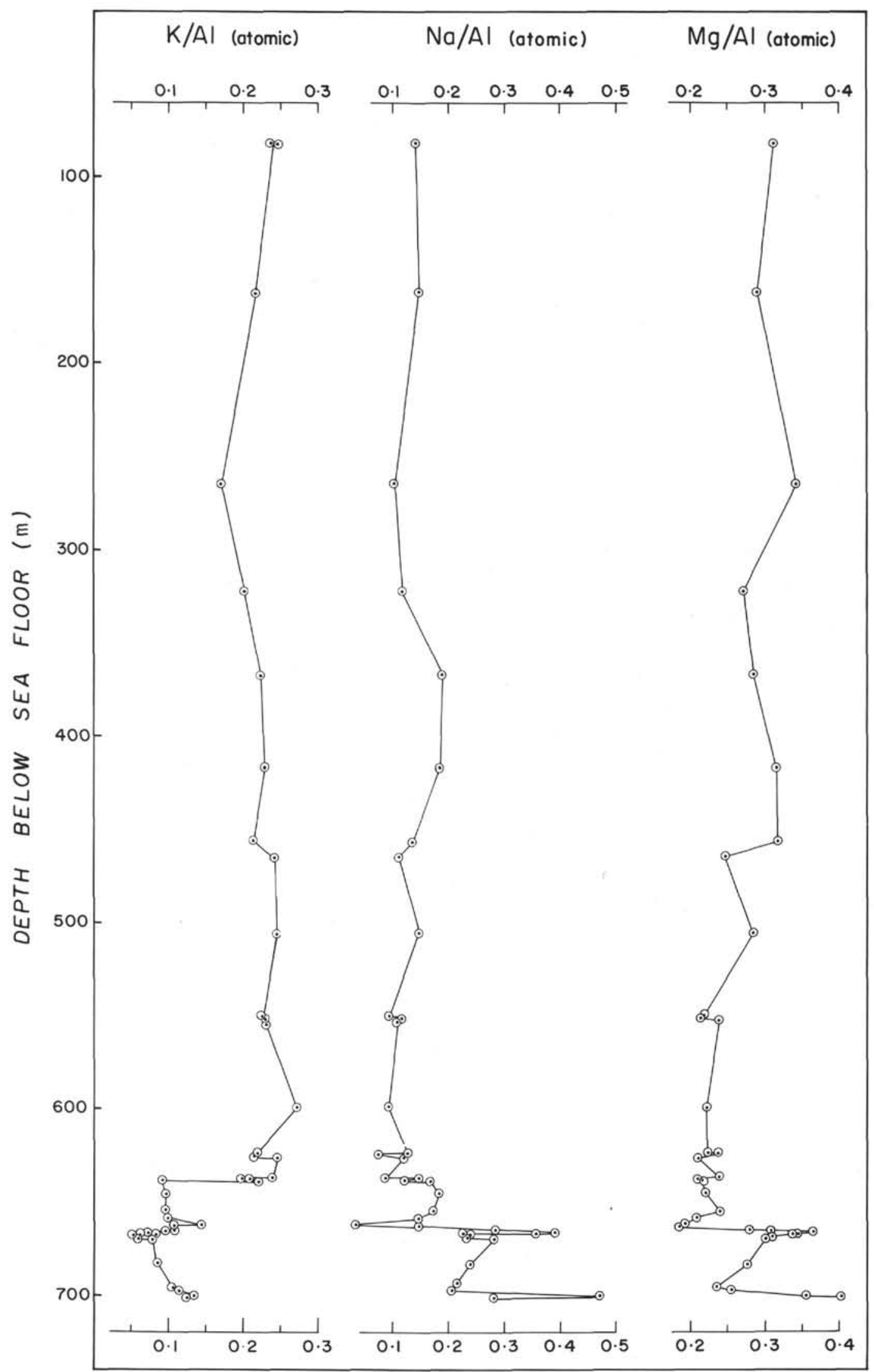

Figure 1. Ratios of $\mathrm{K}, \mathrm{Na}$, and $\mathrm{Mg}$ to Al in clay fraction, Site 323. 


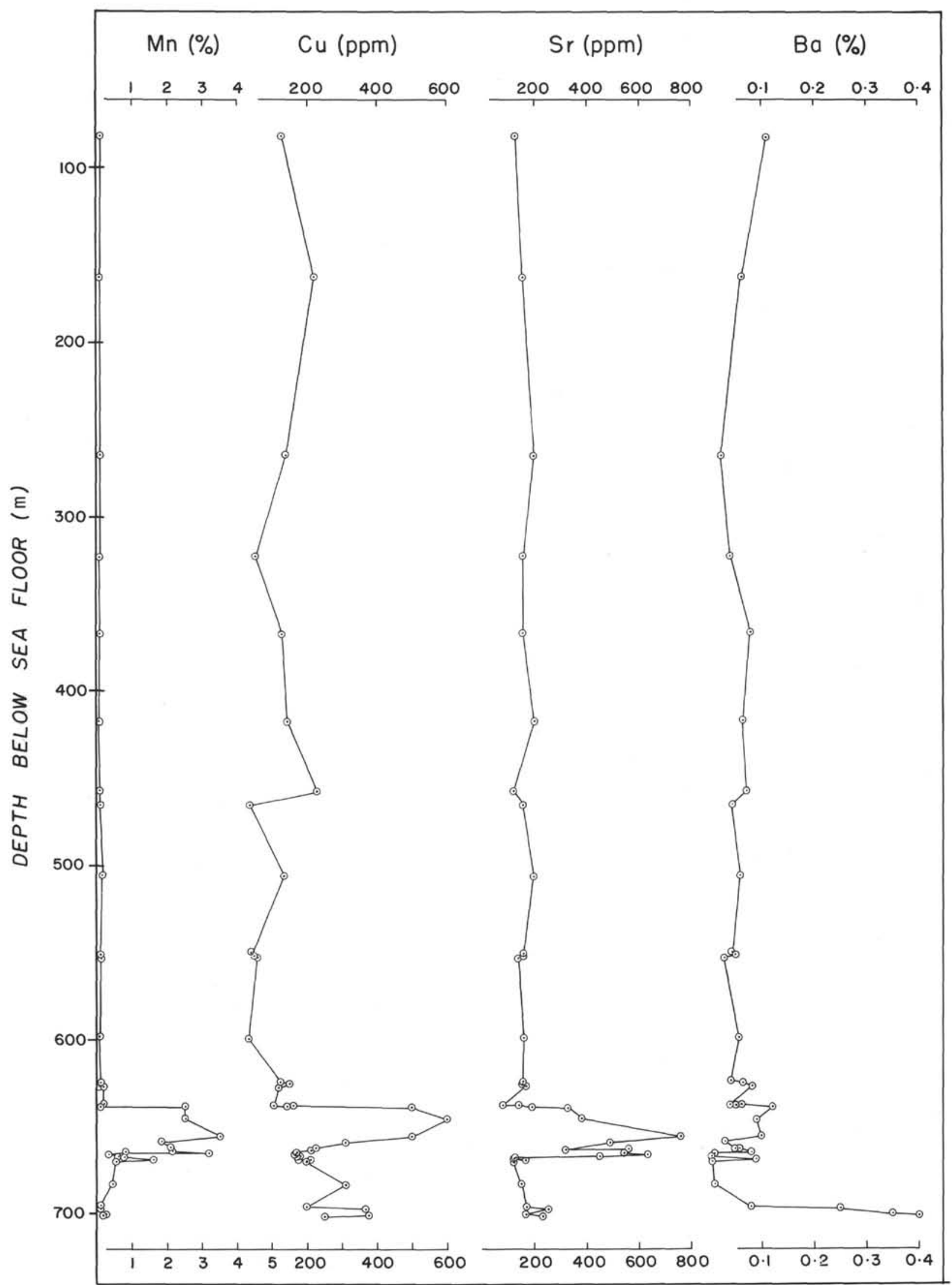

Figure 2. Minor element content of clay fraction, Site 323. 
difference does not reflect any major difference in degree of alteration. Compared to typical unaltered basalt, the altered chip is depleted in $\mathrm{CaO}$ and $\mathrm{MgO}$, and greatly enriched in $\mathrm{K}_{2} \mathrm{O}$. This is the normal pattern for submarine alteration of basalt. Under the scanning electron microscope, secondary K-feldspar can be seen in defects in the plagioclase crystals, presumably accounting for the increased $\mathrm{K}_{2} \mathrm{O}$. The relationships between basalt alteration and interstitial water chemistry will be discussed in the next section.

\section{SOLID PHASES AND \\ INTERSTITIAL WATER CHEMISTRY}

The interstitial water data (Gieskes, this volume) suggest that reactions which release calcium and take up magnesium occur in the upper 170 meters, at approximately 450 meters, and in the basal sediments or underlying basalt. Since we have only one sample from above 170 meters, no statements can be made regarding reactions occurring in that interval. At 450 meters there are no obvious changes in the mineralogy of chemistry of the clay fraction. It appears (Kastner, this volume) that the controlling reactions are closely associated with localized porcelanite formation. Uptake and release reactions in the basal 60 meters are difficult to evaluate, as the chemistry and mineralogy of these sediments at the time of burial are not known. The $\mathrm{Mg} / \mathrm{Al}$ ratio in the clays of the basal 60 meters is higher than in the overlying sediments, but difference cannot be related to diagenetic changes unless the initial composition is known. The principal Mg-bearing phase in the basal 60 meters is smectite, which could have formed in situ after burial, or could have formed on the sea floor prior to burial. Isotopic studies are now in progress to answer this question.

The gradients in interstitial calcium and magnesium appear to continue to the base of the sediments, and it is probable that magnesium uptake and calcium release are occurring within the basalt. Isotopic studies (Anderson and Lawrence, this volume; Lawrence et al., this volume) indicate extensive interaction between the pore water and the underlying basalt. For calcium the process appears to be simple release of calcium from alteration of pyroxenes or plagioclase and diffusion of $\mathrm{Ca}^{++}$ through the overlying sediments. The process controlling $\mathrm{Mg}^{++}$cannot be as simple. The basalt appears to be acting as a sink for $\mathrm{Mg}^{++}$in the interstitial water, and yet the altered basalt contains less $\mathrm{MgO}$ than fresh basalt. This discrepancy can be explained by either of two hypotheses:

1) When the basalt is first extruded and altered there is relatively free circulation of seawater, and the water at the sites of alteration has essentially the same $\mathrm{CO}_{2}$ content and $p \mathrm{H}$ as seawater. Under these conditions $\mathrm{Mg}$ is leached from the basalt. When the basalt is buried and continues to alter, water circulation is restricted, $\mathrm{CO}_{2}$ is depleted by the alteration process, and the $p \mathrm{H}$ rises. At slightly elevated $p \mathrm{H}$ values $\mathrm{Mg}$ becomes fixed in smectites (Deffeyes, 1965, discussed in Drever, 1974), causing a depletion of $\mathrm{Mg}^{++}$in the interstitial water and the establishment of the observed diffusion gradient.

2) When the basalt is first altered it loses $\mathrm{Mg}$ and forms a metastable secondary phase. Over a long period of time the metastable phase recrystallizes to stable phases, and during this recrystallization $\mathrm{Mg}$ is taken up from solution.

Experiments are now underway to test these hypotheses.

The interstitial $\mathrm{K}^{+}$concentration drops to essentially zero some distance above the basalt-sediment contact. This suggests that $\mathrm{K}$ uptake is occurring within the basal sediments. Authigenic K-feldspar in the basal sediments and within the basalt is an obvious sink for $\mathrm{K}$, but, unless anomalously high $p \mathrm{H}$ values or dissolved aluminum values are postulated, K-feldspar should be undergoing alteration rather than growth in the present-day interstitial water. It is possible that the $\mathrm{K}$-feldspar is relict from a time when the interstitial water chemistry was different, and the present-day control of $\mathrm{K}^{+}$is uptake by clinoptilolite or by the smectite. The X-ray diffraction patterns of the basal 60 meters of sediment show no evidence for the development of illitic interlayers, but the $\mathrm{K} / \mathrm{Al}$ ratios of the clays (which are dominated by smectite) are quite variable; and the variation may reflect formation of a few illitic layers which are not yet sufficiently numerous to be detected by X-ray diffraction.

\section{ACKNOWLEDGMENTS}

Much of the analytical work was done by J.W. Murphy, C.D. Sands, and W.R. Cook, III, to whom the author is most grateful. R.C. Surdam, J.R. Boles, and P. Ogden provided helpful advice on the identification and significance of laumontite. The author benefited greatly from discussions with other members of the Leg 35 Geochemistry Group. The work was financed by NSF Grant GA-33503.

\section{REFERENCES}

Boles, J.R. and Coombs, D.S., 1975. Mineral reactions in zeolite Triassic tuff, Hokonui Hills, New Zealand: Geol. Soc. Am. Bull., v. 86, p. 163-173.

Boström, K. and Peterson, M.N.A., 1966. Precipitates from hydrothermal exhalations on the East Pacific Rise: Econ. Geol., v. 61, p. 1258-1265.

Buckley, D.E. and Cranston, R.E., 1971. Atomic absorption analyses of 18 elements from a single decomposition of aluminosilicate: Chem. Geol., v. 7, p. 273-284.

Drever, J.I., 1973. The preparation of oriented clay mineral specimens for X-ray diffraction analysis by a filtermembrane peel technique: Am. Mineralogist, v. 58, p. 553554.

, 1974. The magnesium problem. In Goldberg, E.D. (Ed.), The sea, ideas and observations, Vol. V, marine chemistry: New York (Wiley-Interscience), p. 337-357.

Deffeyes, K.S., 1965. The Columbia River flood and the history of the oceans: Pacific N.W. Oceanogr. Ann. Mtg., Corvallis, Oregon.

Furbish, W.J., 1965. Laumontite-leonhardite: Southeastern Geol., v. 6, p. 189-200.

Horn, R.R., 1968. Authigenic prehnite, laumontite and chlorite in the lower Cretaceous sediments of south-eastern Alexander Island: British Antarctic Surv. Bull., v. 18, p. 110.

Perry, E. and Hower, J., 1970. Burial diagenesis in Gulf Coast pelitic sediments: Clays Clay Minerals, v. 18, p. 165-177.

Reynolds, R.C. and Hower, J., 1970. The nature of interlayering in mixed-layer illite-montmorillonites: Clays \& Clay Minerals, v. 18, p. 25-36. 